\title{
PENGARUH PERTUMBUHAN EKONOMI, TINGKAT INFLASI, DAN PERTUMBUHAN PENDUDUK TERHADAP TINGKAT PENGANGGURAN TERBUKA DI INDONESIA
}

\author{
Irma Yuni Astuti ${ }^{1}$ \\ Email:yunii73@yahoo.co.id
}

Nanik Istiyani

Lilis Yuliati ${ }^{3}$

\begin{abstract}
This study aims to determine the effect of economic growth, inflation and population growth in open unemployment rate in Indonesia. The type of data used in this study is secondary data in the form of time series data and variable data used are annual data in the period 1986-2017 with the object of research in the country o Indonesia. The data sources used in this study were obtained from the Central Statistics Agency (BPS) Indonesia and World Bank. The analytical method used in this study is multiple linear regression analysis with the Ordinary Least Square (OLS) technique. The estimation of time series data with multiple linear regression analysis shows that the economics growth variable has a positive and not significant effect on the level of open unemployment, the inflation variable has a positive and not significant effect on the level of open unemployment, and the population growth variable has a negative and significant effect on the level of open unemployment in Indonesia.
\end{abstract}

Keywords: Open Unemployment, Economic Growth, Inflation, Population Growth

\section{PENDAHULUAN}

Pembangunan ekonomi pada hakekatnya adalah serangkaian usaha yang bertujuan untuk meningkatkan taraf hidup masyarakat, memperluas kesempatan kerja dan mengarahkan pembagian pendapatan secara merata. Pembangunan secara lebih

\footnotetext{
${ }^{1}$ Corresponding Author: Uurusani Ilmu Ekonomi dan Studi Pembangunan, Fakultas Ekonomi dan Bisnis, Universitas Jember, Jalan Kalimantan No. 37, Kampus Tegalboto, Kecamatan Sumbersari, Jember, 68121, Jawa Timur, Indonesia.

2,3 Jurusani Ilmu Ekonomi dan Studi Pembangunan, Fakultas Ekonomi dan Bisnis, Universitas Jember, Jalan Kalimantan No. 37, Kampus Tegalboto, Kecamatan Sumbersari, Jember, 68121, Jawa Timur, Indonesia.
} 
luas dapat diartikan sebagai usaha untuk lebih meningkatkan produktivitas sumber daya potensial yang dimiliki oleh suatu negara, baik sumber daya alam, sumber daya manusia, kapital ataupun modal maupun sumber daya lainnya yang berupa teknologi, dengan tujuan akhirnya adalah untuk meningkatkan taraf hidup kesejahteraan masyarakat secara keseluruhan (Todaro 2000).

Pembangunan ekonomi selain menstabilkan kegiatan ekonomi juga menciptakan pertumbuhan ekonomi yang tangguh serta menghindari masalah inflasi. Dalam pembangunan ekonomi Indonesia kesempatan kerja masih menjadi masalah utama. Hal ini timbul karena adanya kesenjangan atau ketimpangan dalam mendapatkannya. Pokok dari permasalahan ini bermula dari kesenjangan antara pertumbuhan jumlah angkatan kerja disatu pihak dan kemajuan berbagai sektor perekonomian dalam menyerap tenaga kerja dipihak lain.

Indonesia merupakan salah satu negara berkembang, yang dalam pengelompokkan negara berdasarkan taraf kesejahteraan masyarakat, dimana salah satu permasalahan yang dihadapi oleh negara berkembang termasuk Indonesia adalah masalah pengangguran. Apabila pengangguran tersebut tidak segera diatasi maka dapat menimbulkan kerawanan sosial dan berpotensi mengakibatkan kemiskinan.

Masalah pengangguran memang selalu menjadi suatu persoalan yang perlu dipecahkan dalam perekonomian negara Indonesia. Selain itu, kondisi perekonomian yang tidak selalu berada dalam keadaan stabil normalnya justru searah dengan kebijakan yang diterapkan memberikan efek pada adanya momentum yang tidak diharapkan dalam pencapaian perekonomian yang lebih baik (Kustono dan Effendi 2016). Seperti halnya krisis ekonomi yang melanda Indonesia pada tahun 1997-1998 telah mengakibatkan ketidakstabilan perekonomian yang sebelumnya berjalan dengan baik dan terkendali.

Fenomena krisis ekonomi yang terjadi memberikan efek pada memburuknya perekonomian domestik, hal ini diperlihatkan dengan kondisi tingkat pertumbuhan ekonomi dalam negeri mengalami guncangan hingga pada titik negatif dengan tingkat pengangguran yang melonjak cukup tajam. Indikator keberhasilan pembangunan ekonomi dapat dilihat dari laju pertumbuhan ekonomi yaitu besar kecilnya Produk Domestik Bruto (PDB) yang diperoleh, kestabilan tingkat inflasi yang dicapai, dan tingkat pengangguran yang terkendali.

Pertumbuhan ekonomi sangat berperan dalam mendukung berkembangnya suatu usaha. Pertumbuhan ekonomi yang terus berlanjut akan dapat mendorong peluang usaha terbuka lebar, output yang dihasilkan naik, penyerapan tenaga kerja dapat optimal. Pertumbuhan ekonomi Indonesia selama tahun 2009-2013 berkisar $6 \%$, angka pertumbuhan tersebut tergolong tinggi. Tetapi pertumbuhan ekonomi tersebut dalam kenyataannya belum mampu menyerap tambahan angkatan kerja yang terjadi setiap tahunnya ditambah jumlah pengangguran yang sudah ada, karena dari $1 \%$ pertumbuhan ekonomi Indonesia hanya mampu menyerap sekitar 400.000 orang tenaga kerja (Fetriyanto 2014).

Kondisi perekonomian dengan tingkat inflasi yang tinggi dapat menyebabkan perubahan-perubahan output dan kesempatan kerja. Tingkat inflasi yang tinggi berdampak pada pengangguran. Bila tingkat inflasi tinggi, dapat menyebabkan angka pengangguran tinggi, ini berarti perkembangan kesempatan kerja menjadi semakin mengecil atau dengan kata lain jumlah tenaga kerja yang diserap juga akan kecil. 
Inflasi mempunyai pengaruh terhadap tingkat pengangguran. Apabila tingkat inflasi meningkat, maka harga-harga barang dan jasa akhir juga akan naik, selanjutnya permintaan akan barang dan jasa akhir akan turun, dan akan mengurangi permintaan terhadap tenaga kerja yang dibutuhkan, akibatnya akan meningkatkan jumlah pengangguran terbuka. Sehingga inflasi mempunyai pengaruh yang negatif terhadap tingkat pengangguran (Sukirno 2006).

Pertumbuhan penduduk juga mempengaruhi adanya tingkat pengangguran karena dengan meningkatnya jumlah penduduk, makan jumlah tenaga kerja dan angkatan kerja juga semakin bertambah. Para angkatan kerja tersebut membutuhkan lapangan pekerjaan dan umumnya di dalam negara berkembang, laju pertumbuhan penduduk lebih besar daripada jumlah lapangan kerja yang ada. Oleh karena itu tidak semua angkatan kerja bisa mendapatkan pekerjaan dan disitu akan timbul pengangguran.

\section{METODE PENELITIAN}

\subsection{Jenis Penelitian}

Penelitian ini merupakan penelitian dengan jenis penelitian hipotesa atau penelitian penjelan, disebut juga explanatory research yaitu metode penelitian yang menjelaskan hubungan antara variabel-variabel bebas dan variabel terikat (Singarimbun dan Effendi 2008). Penelitian ini akan menjelaskan tentang pengaruh antara pertumbuhan ekonomi, inflasi, dan pertumbuhan penduduk terhadap tingkat pengangguran terbuka di Indonesia.

\subsection{Jenis dan Sumber Data}

Jenis data yang digunakan dalam penlitian ini merupakan data sekunder yang berupa data time series dan data variabel yang digunakan merupakan data tahunan pada rentang waktu tahun 1986-2017 dengan objek penelitian di negara Indonesia. Sumber data yang digunakan dalam penelitian ini diperoleh dari berbagai sumber, yaitu dari Badan Pusat Statistik (BPS) Indonesia dan World Bank.

\subsection{Spesifikasi Model Penelitian}

Penyusunan model yang digunakan dalam penelitian ini mengadopsi dari Mulyati (2009) dengan bentuk model ekonomi sebagai berikut:

$$
T P T_{t}=f\left(P D B_{t}, I N F_{t}, P O P_{t}\right)
$$

Kemudian model tersebut ditransformasikan ke dalam sebuah model ekonometrika, menjadi:

$$
T P T t=\beta_{0}+\beta_{1} P E_{t}+\beta_{2} I N F_{t}+\beta_{3} P P_{t}+e_{t}
$$

dimana:

$\begin{array}{ll}\beta_{1} & : \text { Konstanta } \\ \beta_{1}, \beta_{2}, \beta_{3} & : \text { Koefisien } \\ \mathrm{e} & : \text { Error term } \\ \mathrm{t} & : \text { Time series } \\ \mathrm{TPT} & : \text { Tingkat Pengangguran Terbuka } \\ \mathrm{PE} & : \text { Pertumbuhan Ekonomi per tahun } \\ \mathrm{INF} & : \text { Tingkat Inflasi per tahun } \\ \mathrm{PP} & : \text { Pertumbuhan Penduduk per tahun }\end{array}$




\section{HASIL DAN PEMBAHASAN}

\subsection{Hasil}

\subsubsection{Statistik Deskriptif}

Analisis deskriptif membahas tentang hasil analisis statistik deskriptif yang akan memberikan gambaran secara umum penggunaan data pada penelitian ini untuk mewakili masing-masing variabel yang digunakan pada model penelitian. Analisis statistik deskriptif menunjukkan perilaku variabel independen dalam mempengaruhi pergerakan variabel dependen. Tingkat variabel dependen adalah tingkat pengangguran terbuka di Indonesia dan variabel independen adalah pertumbuhan ekonomi, inflasi dan pertumbuhan penduduk, berikut adalah hasil analisis deskriptif:

Tabel 1. Nilai Mean, Median, Maximum, Minimum, dan Standar Deviasi Tiap Variabel

\begin{tabular}{lcccc}
\hline & TPT & PE & INF & PP \\
\hline Mean & 13,96 & 5,07 & 9,4 & 1,47 \\
Median & 15,21 & 5,62 & 7,14 & 1,39 \\
Max & 24,39 & 8,22 & 58,45 & 2,03 \\
Min & 2,55 & -13.13 & 3,52 & 1,09 \\
Std. Dev & 6,47 & 3,60 & 9,56 & 0,24 \\
\hline Observations & 32 & 32 & 32 & 32 \\
\hline Sumber : Lampiran A, diolah & & &
\end{tabular}

Berdasarkan Tabel 4.1 berkaitan dengan analisis deskriptif statistik dapat dilihat bahwa tingkat pengangguran terbuka mempunyai rata-rata sebanyak $13,96 \%$, dengan nilai minimal 2,55\% dan maksimal 24,39\%. Variabel pertumbuhan ekonomi mempunyai rata-rata sebanyak $5,07 \%$ dengan nilai minimal $-13,12 \%$ dan maksimal $8,22 \%$. Variabel inflasi mempunyai rata-rata dengan nilai minimal 3,52\% dan nilai maksimal 58,45\%. Kemudian variabel pertumbuhan penduduk mempunyai rata-rata sebanyak $1,47 \%$ dengan nilai minimal $1,09 \%$ dan jumlah maksimal sebanyak 2,03\%. Jumlah observasi pada penelitian sebanyak 32 .

\subsubsection{Analisis Regresi Linier Berganda}

$$
\begin{gathered}
T P T_{t}=\beta_{0}+\beta_{1} P E_{t}+\beta_{2} I N F_{t}+\beta_{3} P P_{t}+e_{t} \\
\text { TPT }=44,59152+0,314814 \mathrm{PDB}+0,178053 \mathrm{INF}-23,08464 \mathrm{POP}
\end{gathered}
$$

Nilai konstanta $\beta_{0}=44,59152$ artinya bila seluruh variabel independen yaitu pertumbuhan ekonomi, inflasi, dan pertumbuhan penduduk diasumsikan memiliki nilai koefisien nol (konstan) maka nilai tingkat pengangguran terbuka sebesar 44,59\%.Nilai koefisien regresi variabel pertumbuhan ekonomi $\beta_{1}=0,31$ artinya jika pertumbuhan ekonomi mengalami kenaikan sebesar $1 \%$ maka tingkat pengangguran terbuka akan meningkat sebesar 0,31. Secara pertumbuhan ekonomi signifikan apabila nilai probabilitas $<\alpha=5 \%$. Koefisien pertumbuhan ekonomi sebesar 0,31 dan probabilitas sebesar 0,57 artinya berpengaruh positif dan tidak signifikan terhadap tingkat pengangguran terbuka di Indonesia.

Nilai koefesien regresi variabel inflasi $\beta_{2}=0,18$ artinya jika inflasi mengalami kenaikan 1\% maka tingkat pengangguran terbuka akan meningkat sebesar 0,18 . Secara statistik inflasi signifikan apabila nilai probabilitas $<\alpha=5 \%$. 
Koefisien inflasi 0,18 dan probabilitas sebesar 0,38 artinya inflasi berpengaruh positif dan tidak signifikan terhadap tingkat pengangguran terbuka di Indonesia.

Nilai koefesien regresi variabel pertumbuhan penduduk $\beta_{3}=-23,08$ artinya jika pertumbuhan penduduk mengalami kenaikan $1 \%$ maka tingkat pengangguran terbuka akan menurun sebesar 23,08. Secara statistik pertumbuhan penduduk signifikan apabila nilai probabilitas $<\alpha=5 \%$. Koefisien pertumbuhan penduduk $-23,08$ dan probabilitas sebesar 0,00 artinya pertumbuhan penduduk berpengaruh negatif dan signifikan terhadap tingkat pengangguran terbuka di Indonesia.

Model ekonometrika yang baik harus memenuhi kriteria ekonometrika dan kriteria statistik. Berdasarkan kriteria ekonometrika, model yang digunakan harus sesuai dengan asumsi klasik, artinya terbebas dari gejala multikolinearitas, autokorelasi dan heteroskedastisitas. Kesesuaian model dengan kriteria statistik dilihat dari hasil uji koefisien determinasi (R2), uji statistik F, dan uji statistik t.

\subsubsection{Uji t (t-test)}

Uji t dilakukan untuk melihat besarnya pengaruh dari tiap-tiap variabel independen terhadap variabel dependen. Variabel independen masing-masing dikatakan signifikan apabila nilai probabilitas t-hitung variabel < tingkat signifikan $(\alpha=5 \%)$, tetapi apabila nilai probabilitas t hitung pada varibel independen $>$ tingkat signifikan maka dapat dikatakan model tersebut tidak signifikan terhadap variabel independen. Berdasarkan uji $\mathrm{t}$ dalam analisis ini dimaksudkan untuk mengetahui tingkat signifikan berpengaruh secara parsial antara variabel bebas (independen) yang meliputi pertumbuhan ekonomi, inflasi dan pertumbuhan penduduk terhadap variabel terikat (dependen) yaitu tingkat pengangguran terbuka.

Tabel 2. Uji F dan Uji t

\begin{tabular}{|c|c|c|c|}
\hline Uji t & Keterangan & Probabilitas Uji F & R-squared \\
\hline 0,5674 & Tidak Signifikan & \multirow{3}{*}{0,000000} & \multirow{3}{*}{0,677506} \\
\hline 0,3850 & Tidak Signifikan & & \\
\hline 0,0000 & Signifikan & & \\
\hline
\end{tabular}

Pada Tabel 4.3 yang merupakan hasil uji t, uji $\mathrm{F}$ dan koefisien determinasi yang telah dilakukan maka diperoleh hasil sebagai berikut:

1. Variabel pertumbuhan ekonomi (PE) memiliki nilai probabilitas $t_{\text {hitungsebesar }}$ 0,5674 maka nilai ini menunjukkan bahwa nilai probabilitas thitunglebih besar daripada nilai signifikan $(\alpha=0,05)$ sehingga variabel pertumbuhan ekonomi tidak signifikan terhadap tingkat pengangguran terbuka di Indonesia,

2. Variabel inflasi (INF) memiliki nilai probabilitas $t_{\text {hitungsebesar } 0,3850 \text { maka nilai }}$ ini menunjukkan bahwa nilai probabilitas thitung lebih besar daripada nilai signifikan $(\alpha=0,05)$ sehingga variabel inflasi tidak signifikan terhadap tingkat pengangguran terbuka di Indonesia,

3. Variabel pertumbuhan penduduk (PP) memiliki nilai probabilitas thitung sebesar 0,0000 maka nilai ini menunjukkan bahwa nilai probabilitas $t_{\text {hitung }}$ lebih kecil daripada nilai signifikan $(\alpha=0,05)$ sehingga variabel inflasi signifikan terhadap tingkat pengangguran terbuka di Indonesia. 


\subsubsection{Uji F (F-test)}

Uji F digunakan untuk menguji signifikan seluruh variabel independen secara bersama-sama dalam mempengaruhi variabel dependen, atau untuk melihat pengaruh variabel-variabel independen secara bersama-sama terhadap variabel dependen. Berdasarkan tabel uji $\mathrm{F}$ untuk menguji secara serentak pengaruh variabel independen terhadap variabel dependen, keempat variabel yaitu, pertumbuhan ekonomi, inflasi dan pertumbuhan penduduk berpengaruh signifikan terhadap tingkat pengangguran terbuka di Indonesia yang ditunjukkan oleh nilai probabilitas $F_{\text {hitung }}$ sebesar 0,00< $\alpha=5 \%$ atau 0,05 , hal ini menunjukkan bahwa $\mathrm{H}_{0}$ ditolak dan $\mathrm{H}_{\mathrm{i}}$ diterima sehingga dapat dikatakan bahwa variabel pertumbuhan ekonomi, inflasi, dan pertumbuhan penduduk secara simultan berpengaruh signifikan terhadap tingkat pengangguran terbuka.

\subsubsection{Koefisien Determinasi $\left(\mathbf{R}^{2}\right)$}

Berdasarkan hasil perhitungan regresi dapat diketahui bahwa nilai koefisien determinasi $\left(\mathrm{R}^{2}\right)$ adalah sebesar 0,677506 . Hal ini berarti bahwa $68 \%$ perubahan nilai realisasi tingkat pengangguran terbuka (TPT) di Indonesia secara bersama-sama mampu dijelaskan oleh variabel independen yang digunakan dalam model, yaitu pertumbuhan ekonomi, inflasi dan pertumbuhan penduduk. Sedangkan sisanya sebesar 32\% dapat dijelaskan oleh variabel lain yang tidak dimasukkan ke dalam model.

\subsubsection{Uji Multikolinearitas}

Tabel 3. Hasil Uji Multikolinearitas

\begin{tabular}{lccc}
\hline & PP & INF & PP \\
\hline PP & 1,000000 & $-0,915751$ & 0,170828 \\
INF & $-0,915751$ & 1,000000 & 0,019991 \\
PP & 0,170828 & 0,019991 & 1,000000 \\
\hline Sumber: Lampiran $C$ & &
\end{tabular}

Dari hasil pengujian multikolinearitas pada Tabel 4.4 didapatkan hasil bahwa tidak ada korelasi antara variabel-variabel bebas (independen) dalam suatu model regresi linier berganda, karena nilai korelasi $<0,80$.

\subsubsection{Uji Linearitas}

Tabel 4. Hasil Uji Linearitas

\begin{tabular}{|c|c|c|c|}
\hline \multirow[t]{2}{*}{$\begin{array}{l}\text { Ramsey RESET Test } \\
\text { Equation } \\
\text { Spesification } \\
\text { Omitted Variabels }\end{array}$} & \multicolumn{2}{|c|}{$\begin{array}{l}\text { : UNTITLED } \\
: \text { TPT C PE INF PP } \\
: \text { Squares of fitted values }\end{array}$} & \multirow[b]{2}{*}{ Probability } \\
\hline & Value & Df & \\
\hline t-statistic & 1,889349 & 27 & 0,0696 \\
\hline F-statistic & 3,569639 & $(1,27)$ & 0,0696 \\
\hline Likelihoodratio & 3,973455 & 1 & 0,0462 \\
\hline
\end{tabular}

Sumber: Lampiran C 


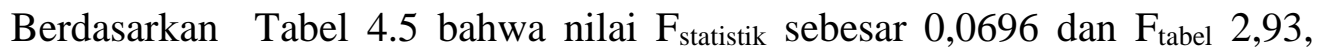
yang berarti $F_{\text {statistik }}<F_{\text {tabel. }}$ Maka dari penjelasan diatas hipotesis diterima atau dikatakan linear.

\subsubsection{Uji Autokorelasi}

Tabel 5. Hasil Uji Autokorelasi

Breusch-Godrey Serial Correlation LM Test

\begin{tabular}{llll}
\hline F-statistic & 39,61903 & Prob. F(2,26) & 0,0000 \\
Obs $*$ - -squared & 24,09411 & Prob. Chi-Square(2) & 0,0000 \\
\hline Sumber: Lampiran C & & &
\end{tabular}

Uji autokorelasi berfungsi untuk mengetahui keberadaan korelasi antara kesalahan pengganggu pada periode $t$ dengan kesalahan pengganggu pada periode $t$ 1. Berdasarkan uji autokorelasi pada Tabel 4.6 diatas, variabel pertumbuhan ekonomi, inflasi dan pertumbuhan penduduk terhadap tingkat pengangguran terbuka di Indonesia terjadi autokorelasi. Hal tersebut ditunjukkan dari nilai probabilitas $(0,00000<0,05)$ dengan signifikansi $(0,05)$ atau derajat keyakinan $5 \%$.

\subsubsection{Uji Heteroskedastisitas}

Tabel 6. Hasil Uji Heterokedastisitas

\begin{tabular}{llll}
\multicolumn{4}{c}{ Heterokedasticity Test: White } \\
\hline F-statistic & 1,304251 & Prob. F(9,22) & 0,2899 \\
Obs*R-squared & 11,13348 & Prob. Chi-Square(9) & 0,2667 \\
Scaled explained SS & 5,883173 & Prob. Chi-Square(9) & 0,7516 \\
\hline
\end{tabular}

Sumber: Lampiran C

Berdasarkan Uji White Cross Term diatas diketahui bahwa model empiris yang mempengaruhi tingkat pengangguran terbuka di Indonesia tidak terdapat masalah heterokedastisitas, karena dapat dilihat pada hasil uji Tabel 4.7 nilai $O b s^{*} R$ squared sebesar 11,13348 >0,05 atau derajat keyakinan 5\%.

\subsubsection{Uji Normalitas}

Gambar 1. Hasil Uji Histogram Normality Test

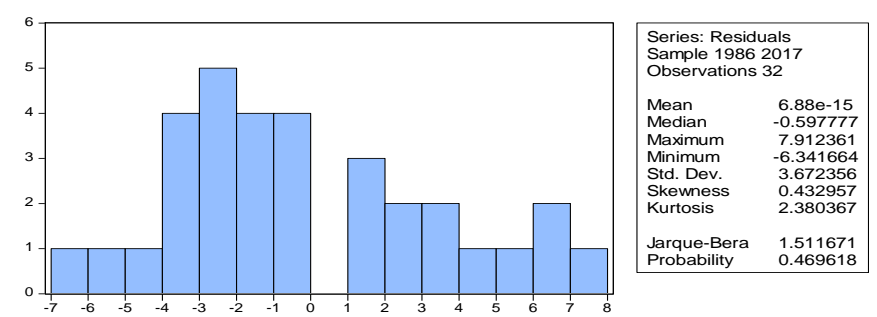

Sumber: Lampiran $C$ 
Berdasarkan hasil pengujian distribusi normal pada Gambar 4.8, variabelvariabel berdistribusi normal karena nilai probabilitas Jarque-Bera test $>0,05$ atau derajat keyakinan 5\%. Nilai probabilitas Jarque-Bera test yaitu sebesar 1,511671.

\subsection{Pembahasan}

\subsubsection{Pengaruh Pertumbuhan Ekonomi terhadap Tingkat Pengangguran Terbuka di Indonesia}

Dari hasil penelitian menunjukkan bahwa pertumbuhan ekonomi berpengaruh tidak signifikan terhadap tingkat pengangguran terbuka di Indonesia. Dilihat dari persamaan regresi diperoleh nilai probabilitasnya adalah sebesar 0,5674 dengan tingkat signifikansi $0,05(5 \%)$. Karena variabel pertumbuhan ekonomi nilai signifikansinya 0,5674 >0,05 sehingga bisa dikatakan bahwa $\mathrm{H}_{0}$ diterima dan $\mathrm{H}_{\mathrm{i}}$ ditolak, dan disini dapat disimpulkan bahwa pertumbuhan ekonomi berpengaruh tidak signifikan terhadap tingkat pengangguran terbuka. Dilihat dari Tabel 4.2 koefisien pertumbuhan ekonomi sebesar 0,31 menunjukkan jika pertumbuhan ekonomi meningkat sebesar $1 \%$ maka akan menaikkan jumlah pengangguran terbuka di Indonesia sebanyak 0,31.

Hasil ini tidak sesuai dengan landasan teori dalam penelitian ini. Studi yang pernah dilakukan oleh ekonom Arthur Okun (Okun's Law) mencoba menjelaskan hubungan antara pertumbuhan ekonomi dengan pengangguran. Hukum Okun menjelaskan bahwa tingkat pengangguran memiliki hubungan negatif dengan GDP riil. Peningkatan pengangguran cenderung dikaitkan dengan rendahnya pertumbuhan GDP riil. Ketika tingkat pengangguran meningkat, maka GDP riil cenderung tumbuh lebih lambat atau bahkan turun.

Menurut Sopianti dan Ayuningsih (2013) pertumbuhan ekonomi merupakan kenaikan kapasitas dari negara bersangkutan untuk menyediakan berbagai barang ekonomi kepada penduduknya, artinya jumlah produksi dalam negeri merupakan ukuran bagi pertumbuhan ekonomi sedangkan saat ini banyak pengalihan tenaga kerja kepada teknologi.

\subsubsection{Pengaruh Inflasi terhadap Tingkat Pengangguran Terbuka di Indonesia}

Dari hasil penelitian menunjukkan bahwa inflasi berpengaruh tidak signifikan terhadap tingkat pengangguran terbuka di Indonesia. Dilihat dari persamaan regresi diperoleh nilai probabilitasnya adalah sebesar 0,3850 dengan tingkat signifikansi $0,05(5 \%)$. Karena variabel inflasi nilai signifikansinya $0,3850>0,05$ sehingga bisa dikatakan bahwa $\mathrm{H}_{0}$ diterima dan $\mathrm{H}_{\mathrm{i}}$ ditolak, dan disini dapat disimpulkan bahwa inflasi berpengaruh tidak signifikan terhadap tingkat pengangguran terbuka. Dilihat dari Tabel 4.2 koefisien inflasi sebesar 0,18 menunjukkan jika tingkat inflasi meningkat sebesar $1 \%$ maka akan menaikkan jumlah pengangguran terbuka di Indonesia sebanyak 0,18 .

Hasil ini tidak sesuai dengan landasan teori dalam penelitian ini. Berdasarkan teori A.W. Phillips menjelaskan bahwa terdapat hubungan yang saling berkaitan antara tingk at inflasi dan tingkat pengangguran. Maka dapat diartikan bahwa dari hasil pengamatannya ternyata ada hubungan yang signifikan antara inflasi dengan tingkat pengangguran, dalam arti jika inflasi tinggi maka pengangguran akan rendah. Hasil penelitian ini sesuai dengan penelitian yang dilakukan oleh Mulyati (2009) tentang Analisis Hubungan Inflasi dan Pengangguran Indonesia periode 1985-2008: Pendekatan Kurva Phillips yang menyatakan bahwa sebenarnya tidak ada hubungan kausalitas antara inflasi dan pengangguran. Tingkat pengangguran ternyata 
dipengaruhi oleh pertumbuhan angkatan kerja dan pengangguran tahun sebelumnya. Dengan demikian, hipotesis yang menyatakan bahwa inflasi berpengaruh negatif terhadap tingkat pengangguran ditolak. Selain itu, keberadaan sektor pertanian dan sektor informal yang menyerap tenaga kerja saat krisis membuat tingkat pengangguran tidak meningkat tajam setajam peningkatan inflasi.

Dalam penelitian Qomariyah (2012) tentang Pengaruh Tingkat Inflasi dan Pertumbuhan Ekonomi terhadap Tingkat Pengangguran di Jawa Timur menyatakan bahwa inflasi berpengaruh tidak signifikan terhadap pengangguran. Berdasarkan analisis deskriptif, inflasi umum di Jawa Timur selama sebelas tahun rata-rata juga dipengaruhi oleh kenaikan kebutuhan pokok, kenaikan minyak dan kenaikan biaya kesehatan, bukan sebagai akibat tarikan permintaan seperti yang dijelaskan dalam Kurva Phillips, sehingga menyebabkan pengaruh tingkat inflasi terhadap tingkat pengangguran di Jawa Timur tidak signifikan (Akhir dan Prabowo 2010). Apabila inflasi di Jawa Timur disebabkan oleh tarikan permintaan maka tingkat inflasi akan berpengaruh signifikan terhadap tingkat pengangguran.

\subsubsection{Pengaruh Pertumbuhan Penduduk terhadap Tingkat Pengangguran Terbuka di Indonesia}

Dari hasil penelitian menunjukkan bahwa pertumbuhan penduduk berpengaruh signifikan terhadap tingkat pengangguran terbuka di Indonesia. Dilihat dari persamaan regresi diperoleh nilai probabilitasnya adalah sebesar 0,0000 dengan tingkat signifikansi $0,05(5 \%)$. Karena variabel pertumbuhan penduduk nilai signifikansinya $0,0000<0,05$ sehingga bisa dikatakan $\mathrm{H}_{0}$ ditolak dan $\mathrm{H}_{\mathrm{i}}$ diterima,dan disini dapat disimpulkan bahwa pertumbuhan penduduk berpengaruh signifikan terhadap tingkat pengangguran terbuka. Dilihat dari Tabel 4.2 koefisien pertumbuhan penduduk sebesar -23,08 menunjukkan jika pertumbuhan penduduk meningkat $1 \%$ maka akan menurunkan jumlah pengangguran terbuka di Indonesia sebanyak 23,08.

Hasil ini tidak sesuai dalam landasan teori dalam penelitian ini. Dalam teori penduduk optimum yang digunakan dalam penelitian ini dijelaskan bahwa ada hubungan positif antara jumlah penduduk dengan jumlah pengangguran (Brown dan Moore 2001). Semakin banyak jumlah penduduk maka akan berakibat pada penurunan pendapatan perkapita, penurunan pendapatan perkapita berarti penurunan dalam pertumbuhan ekonomi juga, jika pertumbuhan ekonomi turun maka semakin besar pula kesmpatan untuk menganggur.

Hasil penelitian ini sesuai dengan penelitian yang dilakukan oleh Kuntiarti (2018) tentang Pengaruh Inflasi, Jumlah Penduduk dan Kenaikan Upah Minimum terhadap Pengangguran Terbuka di Provinsi Banten tahun 2010-2015 yang menyatakan bahwa jumlah penduduk berpengaruh negatif terhadap pengangguran terbuka. Hal ini dibuktikan dengan tren tingkat pengamgguran terbuka di Provinsi Banten pada tahun 2010-2015 yang mengalami penurunan dari 13,68\% menjadi 9,55\% seiring dengan peningkatan jumlah penduduk dari 10.632 .166 jiwa menjadi 11.955.243 jiwa di Provinsi Banten selama periode tahun 2010-2015. Ketika jumlah penduduk bertambah banyak maka perusahaan-perusahaan akan lebih mudah dalam mendapatkan tenaga kerja. Selain itu upah yang diberikan oleh perusahaan pun menjadi rendah. Semakin banyak yang terserap dalam perusahaan akan memberikan dampak pada pembangunan ekonomi. Pembangunan ekonomi akan semakin cepat dengan diikuti oleh perluasan kesempatan kerja sehingga akan mengurangi banyaknya jumlah pengangguran. 


\section{KESIMPULAN DAN SARAN \\ 4.1 Kesimpulan}

Berdasarkan hasil analisis dan pembahasan data, penulis memperoleh kesimpulan yang dapat diambil dari penelitian mengenai pengaruh pertumbuhan ekonomi, inflasi dan pertumbuhan penduduk terhadap tingkat pengangguran terbuka di Indonesia tahun 1986-2017 sebagai berikut:

a. variabel pertumbuhan ekonomi memiliki pengaruh positif dan tidak signifikan terhadap tingkat pengangguran terbuka di Indonesia,

b. variabel tingkat inflasi memiliki pengaruh positif dan tidak signifikan terhadap tingkat pengangguran terbuka di Indonesia,

c. variabel pertumbuhan penduduk memiliki pengaruh negatif dan signifikan terhadap tingkat pengangguran terbuka di Indonesia.

\subsection{Saran}

Berdasarkan kesimpulan di atas, dapat disimpulkan berberapa saran yang diharapkan dapat bermanfaat bagi pemerintah, maupun pihak-pihak lain. Adapun saran yang dapat diberikan, antara lain:

a. untuk meningkatkan pertumbuhan ekonomi berkelanjutan diperlukan upaya pemerintah dalam mengembangkan semua aspek yang berkaitan dengan perekonomian Indonesia. Hal itu bisa dimulai dari menyediakan sarana dan prasarana di sekolah-sekolah, kualitas para pengajar, penyesuaian penjurusan sekolah dengan kebutuhan industri, dan sebagainya. Diharapkan dengan adanya perbaikan dari hulu hingga hilir, pendidikan para anak bangsa akan semakin meningkat dan mampu bersaing dengan negara lainnya. Jangan sampai kesempatan kerja di dalam negeri yang begitu besar diambil oleh tenaga asing terlatih dengan skill yang lebih baik daripada para tenaga kerja yang dimiliki Indonesia,

b. untuk mengatasi masalah inflasi sebaiknya pemerintah melakukan kebijakan fiskal yang mampu menekan laju inflasi tetapi tidak menyebabkan peningkatan pengangguran seperti dengan melakukan pengeluaran untuk infrastruktur dan pengeluaran lain yang mampu menciptakan investasi,

c. untuk menekan laju pertumbuhan penduduk diperlukan upaya pemerintah dalam merealisasikan usaha tersebut. Pemerintah seharusnya meningkatkan pelayanan kesehatan dan kemudahan dalam menjadi akseptor Keluarga Berencana (KB), mempermudah dan meningkatkan pelayanan dalam bidang pendidikan, sehingga keinginan untuk segera menikah dapat dihambat, meningkatkan wajib belajar pendidikan dasar bagi masyarakat, dari 6 tahun menjadi 9 tahun.

\section{DAFTAR PUSTAKA}

Akhir, dan Prabowo. 2010. Pengaruh Pengungkapan Laporan Lingkungan dan Laporan Sosial Perusahaan terhadap Harga Saham. Skripsi. Jurusan Akuntansi Fakultas Ekonomi Universitas Diponegoro. Semarang.

Brown, L. D., dan M. H. Moore. 2001. Accountability, a Strategy, and International Non Government Organization. Working Paper, Harvard University.

Fetriyanto, N. 2014. Ekonomi Sumber Daya Manusia dalam Perspektif Indonesia. Yogyakarta: UPP STIM YKPN. 
Kuntiarti, D. D. 2018. Pengaruh Inflasi, Jumlah Penduduk dan Kenaikan Upah Minimum terhadap Pengangguran Terbuka di Provinsi Banten tahun 20102015. Fakultas Ekonomi Universitas Negeri Yogyakarta.

Kustono, A. S., dan R. Effendi. 2016. Earnings Management and Corporate Governance Case in Indonesia. Advanced Science Letters 22:4345-4347.

Mulyati, S. 2009. Analisis Hubungan Inflasi dan Pengangguran di Indonesia periode 1985-2008. Skripsi. Bogor: IPB.

Qomariyah, I. 2012. Pengaruh Tingkat Inflasi dan Pertumbuhan Ekonomi terhadap Tingkat Pengangguran di Jawa Timur. Jurnal Ekonomi : Universitas Negeri Surabaya.

Singarimbun, M., dan S. Effendi. 2008. Metode Penelitian Survei. Jakarta : LP3ES Indonesia Anggota IKAPI.

Sukirno, S. 2006. Mikro Ekonomi Teori Pengantar edisi Ketiga Jakarta : PT. Raja Grafindo Persada.

Todaro, M. P. 2000. Pembangunan Ekonomi di Dunia Ketiga, edisi 7. Jilid 1. PT. Gelora Aksara Pratama. Jakarta: Penerbit Erlangga. 